\title{
Ecotourism in Eaglesnest, West Kameng, Arunachal Pradesh: A Case Study
}

Peter Lobo*

\section{Abstract}

This study was aimed at exploring tourism resources and Ecotourism behaviour of tourists and local people to provide guidelines for Ecotourism development of Eaglesnest, West Kameng, Arunachal Pradesh. Tourists were selected by applying the method of convenience sampling, wherein, local people were interviewed in depth to gather local information. Results of the research showed that Eaglesnest had an outstanding tourism resource which was Bird watching, especially after the discovery of the new species of bird to the world, which is known as Bugun Liochicla, which attracted tourists from all over the world. Most of the tourists received tourism information from trip reports and advertising. They were normally grouped visitors who visited the destination for wildlife, especially Bird watching. On an average, they stayed over seven nights at different campsites. Nearly all tourists were aware of Ecotourism. The most attractive resource was Bird watching. They also admired the landscapes, the scenery of the forest and mountains.

Keywords: Bird watching; Ecotourism; Eaglesnest, Tourists; Bugun; Sherdukpen.

\section{Introduction}

Arunachal Pradesh attained its statehood on 20th February 1987. It is situated in the North-Eastern part of India with 83,743 sq. kms

\footnotetext{
* Phd Scholar, School of Tourism and Hospitality Services Management Block 1, IGNOU Maidan Garhi, New Delhi 110068; peterlobo65@gmail.com
} 
area and has a long international border with Bhutan to the west $(160 \mathrm{~km})$, China to the north and north-east $(1,080 \mathrm{~km})$ and Myanmar to the east $(440 \mathrm{~km})$. It stretches from snow-capped mountains in the north to the plains of Brahmaputra valley in the south. Arunachal Pradesh is the largest state, area wise in the north-east region, even larger than Assam which is the most populous. It is situated between latitude $26^{\circ} 30^{\prime} \mathrm{N}$ and $29^{\circ} 30^{\prime} \mathrm{N}$ and longitude $91^{\circ} 30^{\prime} \mathrm{E}$ and $97^{\circ} 30^{\prime} \mathrm{E}$. Itanagar is the capital of Arunachal Pradesh. West Kameng District of Arunachal Pradesh State in the Indian sub-continent lies somewhere between $91^{\circ} 30^{\prime}$ to $92^{\circ} 40^{\prime}$ East longitudes and $26^{\circ} 54^{\prime}$ to $28^{\circ} 01^{\prime}$ North latitudes. The District is surrounded by the Tibet region of China in the North, Bhutan in the West, Tawang District and East Kameng District of Arunachal Pradesh are in the Northwest and East respectively and the Southern boundary adjoins the Sonitpur District of Assam. The District has vast tourism potential. Like other parts of the North East Frontier Agency (NEFA), it was also under the Ministry of External Affairs and overall in-charge of the District was a 'Political Officer. Later on Kameng Frontier Division was renamed as 'Kameng District', and the Political Officer was designated as 'Deputy Commissioner'. On 1st June 1980, Kameng District was again bifurcated into 'East Kameng District' and 'West Kameng District.

Eaglesnest Wildlife Sanctuary is a protected area of India in the Himalayan foothills of West Kameng District, Arunachal Pradesh. It conjoins Sessa Orchid Sanctuary to the northeast and Pakhui Tiger Reserve across the Kameng river to the east. The Altitude ranges extremely from 500 metres $(1,640 \mathrm{ft})$ to 3,250 meters $(10,663 \mathrm{ft})$. It is a part of the Kameng Elephant Reserve. Eaglesnest is notable as a prime bird watching site due to its extraordinary variety, numbers and accessibility of bird species there. After the discovery of a new Liocichla in 2005, many birders made the birding pilgrimage to this north-east corner of India. Thereby, making it a popular bird watching destination in the recent years.

At Eaglesnest, you bird along this wide track from Lama Camp $(2300 \mathrm{~m})$ up to Eaglesnest Pass $(2700 \mathrm{~m})$ and then down to Bhompu (1900 m), Sessni (1200 m), Khellong and further down to the Doimara River $(700 \mathrm{~m})$. The Tourists stayed in the tented camps 
at Lama Camp and Bhompu and from these camps, they birded along the different stretches of the road. The birding along this track with no traffic and through mostly undisturbed, pristine habitat was absolutely fabulous. This Sanctuary is surrounded by two tribes, Bugun and Sherdukpen .

Eaglesnest is an excellent showcase for biodiversity between $400 \mathrm{~m}$ and $3000 \mathrm{~m}$. Other areas in the vicinity like Kaziranga $(50 \mathrm{~m}$; grassland and woodland), Nameri (100m; swamp forests), Pakke (100-300m; lowland evergreen foothill forest) and Dirang (1500$4200 \mathrm{~m}$; conifers, alpine scrub etc) complete the suite of biodiversity of this region.

\section{Review of Literature}

West Kameng lies approximately between $91^{\circ} 30^{\prime}$ to $92^{\circ} 40^{\prime}$ East longitudes and $26^{\circ} 54^{\prime}$ to $28^{\circ} 01^{\prime}$ North latitudes. The district shares an international border with Tibet in the north, Bhutan in the west, Tawang District in the northwest, and East Kameng district in the east. The southern border is shared with Sonitpur district and Darrang district of Assam

The topography of the district is mostly mountainous. A greater part of it, falls within the higher mountain zone, consisting of a mass of tangled peaks and valleys. In West Kameng, there are three principle mountain chains - part of Sela range, Bomdila range and Chaku range. The Sela range consists of a series of mountains arranged in the form of a big line from Tibet in the north to Bhutan in the west and thus forming a tough terrain to pass through. The altitude of the Sela range varies from 14,000 to 15,000 feet and the Sela pass is 13,714 feet high. The Bomdila range has an average height of 9000 feet. In the South of Bomdila range lies the Chaku range, (foot-hills range) having hills of quite low altitudes and is full of tropical forests, with trees of great economic value and various types of wild games.

The district is divided into three administrative sub-divisions viz. Bomdila, Thrizino, and Rupa and two independent Additional Deputy commissioner's office at Singchung and Dirang. All the circle headquarters of the district are connected with the district headquarters (Bomdila) by roads. Regular passenger services to 
Guwahati, Tezpur, Itanagar, Tawang and all the circle headquarters of the district are being provided by State Transport and private buses. Bhalukpong is the nearest railway station in the district situated at about $100 \mathrm{~km}$ from Bomdila, while Salonibari (Tezpur, Assam) is the nearest airport about $160 \mathrm{~km}$ from the district headquarters (westkameng.nic.in).

Eaglesnest Wildlife Sanctuary is a protected area of India in the Himalayan foothills of West Kameng District, Arunachal Pradesh. It conjoins Sessa Orchid Sanctuary to the northeast and Pakke (Pakhui) wildlife sanctuary and Tiger Reserve across the Eaglesnest is notable as a prime birding site due to the extraordinary variety, numbers and accessibility of bird species there.

Eaglesnest and Sessa sanctuaries- Recommended citation BirdLife International (2012) Important Bird Areas factsheet: Eaglesnest and Sessa Sanctuaries (BirdLife International (2006) \& BirdLife IBA Factsheet)

Our next destination was the famed Eaglesnest Wildlife Sanctuary. This area provides the first barrier to the monsoons heading towards Assam, and the resulting heavy rains had caused a number of major landslides along the track. With no military bases around here, keeping this road clear wasn't a priority as we weren't sure how far we'd be able to get there. However, we at least managed to bump and grind our way to Lama Camp, in the Bugun community area (Davies \& Miller, 2010)

\section{Research Objectives}

1. To explore the resources of Ecotourism in Eaglesnest, West Kameng District

2. To study the behaviour of Eco tourists, local Bugun and Sherdukpen Tribe

3. To provide guidelines for development of Ecotourism

\section{Scope of the Study}

The study undertaken covers the participants from various destinations and their interest towards bird watching at Eaglesnest 
and Wildlife Sanctuary and surroundings due to the popularity created by the recent discovery of the new species of birds.

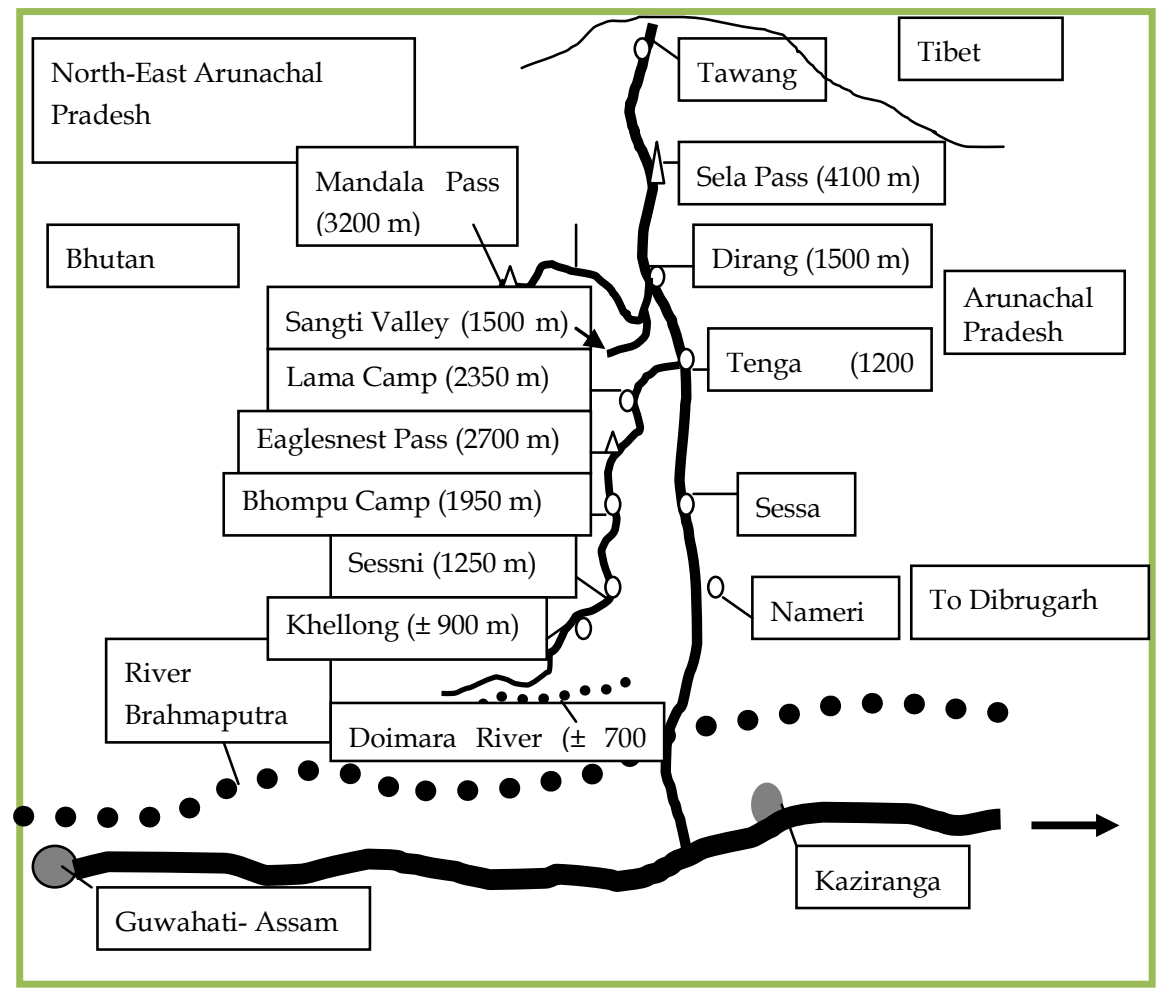

Fig. 1: Sketch map of Eaglesnest

Sampling: The subjects of this research were put in two groups.

Local Bugun \& Sherdukpen Tribe who have been living around the Eaglesnest Wildlife Sanctuary.

\section{Tourists who visited Eaglesnest Wildlife Sanctuary:}

The questionnaires and in depth interviews were conducted from 01 December 2010 to 31st March 2011, in order to collect the research data. 80 man days were necessary to collect the required samples and results, and they were helped by Abidur Rahman, Chewang Bonpu, Rofickul Islam and Sudesh Pradhan, The samples of 50 tourists were selected by convenience sampling method whereas, 10 local people were in depth interviewed to gather local information. 


\section{Research Methodology}

After data forms, the checklist forms, and questionnaires for tourism resources were filled in, the data was examined for accuracy again. Tools used for data collection are divided into 4 parts:

1. Tourism resources checklist.

2. Facilities surveys.

3. Interview of Bugun and Sherdukpen Tribe.

4. Questionnaire for Tourists visiting Eaglesnest Wildlife Sanctuary

The process followed for statistical analysis is as follows: Questionnaires were collected for verifying the accuracy of the data.

\section{Data Analysis}

Basic statistics, such as finding the percentage to interpret basic data

Finding the mean value to interpret the assessment data from various tourism resources

Finding the standard deviation to interpret the tourism resources

The comments are based on SWOT analysis, which includes strengths, weaknesses, opportunities and threats in ecotourism development of Eaglesnest Wildlife Sanctuary (EWLS). For statistical analysis, hypothesis test was applied to compare the needs of tourists for the planning of tourism development in Eaglesnest Wildlife Sanctuary. The Average and standard deviation of the gathered were illustrated.

\section{Survey Result of Tourism Resources}

To explore tourism opportunities in Eaglesnest Wildlife Sanctuary, I found the following resources: 


\section{Natural resources}

Bird watching, Mammal Watching, Herpetofauna Watching, Butterfly Watching

\section{Service Resources}

Accommodations such as Camps: Lama Camp is $10 \mathrm{~km}$ beyond Ramalingam FRH and midway between the latter and the Eaglesnest Pass. The Eaglesnest Biodiversity Project has plannned for making Lama Camp, a research station to facilitate its field activities. The Bugun community has set up the Phua Rung facility for visitors at Lama Camp. It consists of several large tents $(3 \mathrm{~m} x$ $3 \mathrm{~m})$, a large canopied dining area and toilet facilities. There are also several concrete shacks, $1 \mathrm{~km}$ further up the road, which can be used by visitors. Sunderview is the equivalent of Lama Camp in terms of altitude, vegetation, excellent bird watching spot and of course mist and rain, rather more of it. A tour group with a vehicle for moving inside the sanctuary would be better off staying at Lama Camp and Sunderview. Sunderview is a compulsory camping site and also the only camping site in Eaglesnest Wildlife Sanctuary.

Forest Permits Tourist and Research permits for Eaglesnest wildlife sanctuary are issued by the Chief Wildlife Warden at the Office of the Principal Chief Conservator of Forests, Forest Department, Government of Arunachal Pradesh, Itanagar. Tourist permits may also be obtained from the Divisional Forest Officer in charge of Pakke and Eaglesnest at Seijusa in East Kameng district.

Inner Line Permits Indians and foreigners require Inner Line Permits (ILP) and Restricted Area Permits (RAP), respectively, to enter Arunachal. ILPs can be obtained from any one of the Secretary (Political), Govt. of Arunachal Pradesh, Itanagar, Arunachal Pradesh Resident Commissioners in Kolkata, New Delhi, Guwhati and several other places in north-east India. Proof of citizenship is sometimes demanded for which a copy of passport, ration card, voter's ID, or driver's license will suffice. This process takes a day (or occasionally two) and can be initiated by a FAX. Tour agencies can also apply for permits on behalf of their clients. Once inside Arunachal, the district officials can either extend the old permit or issue a new one. RAPs can be obtained 
from Indian embassies/consulates, the easiest for a single-country group. The 30-day permit requires a group of 4-14 tourists all with valid visas and costs $50 \$$ per person (minimum $200 \$$ per group, i.e. 4 people). Permits can be obtained within a week, though it is safer to process it one month in advance. It is mandatory for the tour to be organized by an Arunachal Pradesh tour operator. In practice, obtaining a permit is part of the tour operator's job. Foreign tourists do not have to do anything other than get an Indian visa and pay the tour operator. These permits are checked at the entry point for Eaglesnest, which is at Balukpong and the entry formalities take only a few minutes.

\section{Facilities Checklist Result}

Eaglesnest Wildlife Sanctuary could only provide some documented literature and photographs in the dining halls of all camps and local guides.

\section{Analysis of Interviewing of the People in the Community}

According to the results, it was found that most of the people of the Bugun \& Sherdukpen tribe were mostly unaware of the word ecotourism, however, they did realize that Eaglesnest Wildlife Sanctuary has abundance of tourism resources and is very rich in Flora and Fauna, and so they were ready to protect it. There was hardly any support from the Government agencies or forest personnel present in the Sanctuary. There was no backing from the Government of any sort. The local Bugun community collected entry fees from tourists, and also vehicle entry fees which were used to maintain the road, which naturally was not enough.

\section{Analysis of Tourists Who Visited EWLS}

Most of the tourists who visited EWLS were mainly International tourists who spent about a week on an average in different Camp sites in EWLS and their purpose of visit was mostly the serious study of birds. A few of them were tourists interested in animal wildlife or butterflies, for which EWLS is equally popular. They came to know about EWLS, mostly from trip reports published on the web www.surfbirding.com, Birding magazines and trips 
advertised and organized by tour companies. Most of them would have liked to travel independently, but could not because foreign tourists are not permitted to travel independently in Arunachal Pradesh.

As mentioned, both camps needed improvement. The camp is maintained by Mr. Indi Glow as Camp 01 Lama Camp was built in on his land. When the understanding of tourists and the locals about ecotourism was compared, it was found that tourists had more understanding of ecotourism and scored 7.50 out of 9 points. They suggested that the local people and tourists should take care about the littering of trash in the sanctuary. They also hoped that the Government would invest on the roads inside the sanctuary, so that travel around the sanctuary would take lesser time. They felt very cold in the camps at night, and suggested that the camps could be sealed properly and warm bedding could be provided.

\section{Suggestions}

In this study, the following guidelines are suggested:

\section{Road development}

Since there is a major road construction of a two lane from the Assam Border continuing right up till Tawang, it is quite risky to travel on these roads due to the landslides which cause road blocks for many hours, this is very frustrating, especially for bird watchers as they lose valuable bird watching time. It was suggested that the Government should speed up the road work and there should be traffic police at all strategic points to control the traffic, when a blockade occurs. Also there should be information centres, informing the people about the road condition from time to time. Every year, the road inside the EWLS is damaged by heavy rains in the region, as the road is a dirt track laid, where there is a lot of work to be done to level the track before the season starts.

Security for tourists: There is no security provided by the forest authorities or other Government agencies, as there is a fear of being kidnapped by militants. Also there is no first aid available, as the nearest hospital which is the Army hospital is very far away, and it 
takes more than 2 hours to reach there, in case of an emergency. Government agencies need to look seriously into this matter.

\section{Community development}

Awareness should be created amongst the local tribes; the government agencies or NGOs should provide training about ecotourism and the importance of tourism resources to the community, to recognize the value of nature and environmental conservation, They could have helped them through educational programs organized by the Government.

\section{Involvement of local communities}

The local tribes should involve themselves in the management of ecotourism. The people in the community should participate in the management of eco-tourism. They should have interaction with the relevant agencies on a regular basis. A long term conservation of the natural resources requires contribution from every member of the tribe surrounding the EWLS. Hunters who are hunting should be encouraged to become guides, as they would know the movement of the animals or birds better, thus providing them with means for living and a reason to give up hunting. Another suggestion is that people could grow local vegetables, keep livestock which could be used for tourists visiting EWLS.

\section{Conclusion}

It was observed that nearly 90 percent of the tourists who visited Eaglesnest Wildlife Sanctuary were only interested in Bird watching or study of the birds and some of them specially came to see the new species of bird "Bugun Liochicla". The rest 10 percent of the tourists were general tourists interested in wildlife. All tourists were nature lovers and were very concerned about the environment and respected the rules of EWLS.

The local community had very little support from the Government and all the work was done by Mr. Indi Glow who is the President of Bugun Welfare Society. A proper Information Centre should be set up by the Government or by the local tribes, so that the tourists can have first-hand information on EWLS. A booklet needs to be published, which can help the people gather information. Since the 
study was done only for three months, more detailed study is required for Ecotourism Development potential in EWLS.

\section{References}

Bird Life International (2006) Bird life IBA factsheet. retrieved from http://www.birdlife.org/datazone/sites/index.html?action=SitHTM Details.asp\&sid $=18041 \& \mathrm{~m}=0$

Davies, A., \& Miller, R. (2010). The biggest twitch, 285. London: Christopher Helm.

Official website of West Kameng District (6/21/2007) http:// westkameng.nic.in/geography.htm 